\title{
Peertechz
}

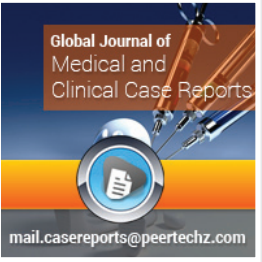

Clinical Group

\section{Global Journal of Medical and Clinical Case Reports}

\section{Adil Omar Bahathiq*}

Department of Physiology, Faculty of Medicine, UmAlqura University, Saudi Arabia

Received: 01 November, 2018

Accepted: 15 November, 2018

Published: 16 November, 2018

*Corresponding author: Adil Omar Bahathiq, Department of Physiology, Faculty of Medicine, Um-Alqura University, Saudi Arabia,

E-mail: drbahathiq@hotmail.com

Keywords: Oral anticoagulants; Bruising of the tongue; Acute respiratory distress

https://www.peertechz.com

Check for updates

\section{Case Report}

\section{A case report on sublingual hematoma}

\author{
Abstract
}

The sublingual hematoma is the cause of bleeding and swelling under the tongue it is commonly seen in the people after some kind of tooth surgery or implant or it can commonly see in the people after a mouth or tongue injury

Demanding intricacies exemplary oral anticoagulants are spoken to by gastrointestinal dying, genitourinary and intracranial. In any case, the hematoma of the dialect is extraordinary. It is accounted for as unconstrained or actuated by a tongue bite, tracheal intubation, yet in addition, can be advanced by fibrinolytic treatment. Its area, the hematoma might be in charge of respiratory misery by deterrent of the upper aviation routes, justifying exceptional thoughtfulness regarding guarantee auspicious administration. We portray the event of dialect hematoma following an overdose of oral anticoagulants, such acenocoumarol (Sintrom $\left.{ }^{\circledR}\right)$, supported by small lingual damage in a 71 years of age understanding conceded for respiratory pain by the obstacle of the upper airways, whose development was ideal.

\section{Introduction}

Oral anticoagulants frequently endorsed to treat a thromboembolic occasion or for its prevention. This remedial class, which is a narrow therapeutic index, defended watchful observing, particularly in the principal long stretches of his medicine, and by and large, near patients in whom the draining danger is high (particularly elderly).

Among the plain couple of confusions, uncommon view, detailed in the writing, is the sublingual hematoma figure 1.

We finally noticed and made a report on this uncommon perception lingual hematoma oral anticoagulant treatment, acenocoumarol (Sintrom ${ }^{\circledR}$ ), and happening in an elderly patient of 71 years.

\section{Case Presentation}

Patient 71 years of age, treated incessantly with acenocoumarol (Sintrom ${ }^{\circledR}$ ) for three months rather ACFA, hospitalized at the intense inpatient unit for relaxing.

Clinical side effects were set apart by the nearness of a substantial hematoma of the dialect influencing exams ear, to nose and throat incomprehensible, joined by trouble breathing

In reality, the establishment of the hematoma was pretty much quickly, inside hours after the damage of the tongue.

At admission, the patient was cognizant, without any indications of restriction; hemodynamically steady, with slight trouble relaxing. Research centre tests were not abnormalities, outside an INR to 5. The administration was symptomatic, in view of the organization of vitamin $\mathrm{K} 10 \mathrm{mg}$ by moderate intravenous new solidified plasma (FFP) at measurements of $20 \mathrm{ml} / \mathrm{kg}$, as a matter of course prothrombin complex think. The advancement was set apart by the emotional relapse of the hematoma following 5 days without going to complete a tracheotomy when the recuperation of oral bolstering and anticoagulant treatment figure 2 .

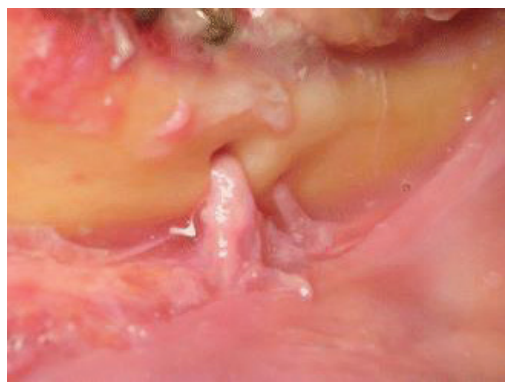

Figure 1:

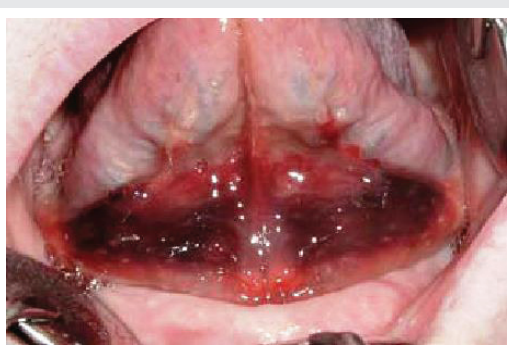

Figure 2 : 


\section{Discussion}

The medicine of oral anticoagulants for different reasons (Thromphlébite individuals, pneumonic embolism, heart valve and so forth ...) isn't without intricacies, particularly dying, justifying watchful checking. The noteworthy recurrence and guess frequently extreme seeping under Vitamin K foe (VKA) make an emotional occasion with a yearly occurrence of deadly seeping of $1 \%$ [1-3]. These hemorrhages happen amid a dosing mistake, poor research centre observing, tranquilize obstruction (quinidine, anti-infection agents ...) [4,5], or Due to damage, even negligible, as the instance of our affected person, who, after a stay quiet, a huge hematoma was at once added. The underestimation of the sore became, to begin with a consultative deferral, a scarcity of statistics on the developing danger of damage. In any case, the nearness of a dialect has to be verified chomp worry the presence of a hematoma. Checking must be watchful retaining in thoughts the quit intention to mediate within the event of an obstacle of the higher aviation route, which has to be executed by means of assembly and brief enmity. Other dialects wounding scenes have been portrayed in writing. $[6,7]$, another with streptokinase with deterrent of the upper aviation route that required nasotracheal intubation [8], and two others in intubated patients in the outcome of thrombolysis $[9,10]$.

We have collected a few data from an article about the sublingual hematoma in the year 1979.

Here they have discussed the three patients who all are having the respiratory misery.

Implies a retropharyngeal and submandibular hematoma. The line to be noticed about the impediment of the upper aviation route lingual hematoma in a patient with heparin has been distributed in 1999 [11]. Another instance of sublingual hematoma was distributed in 2012 out of a patient of 71 years under antivitamins happened after dental injury [12].

The above figure is clearly representing the sublingual hematoma with the swelling of the tongue touching the tooth with its swelling. The swelling is not the main reason for sublingual hematoma but, also there are many chances of attacking Painful swelling in the mouth.

The mucosa over the part of the tongue may result slowly attacking to both sides of the tongue. This is the reason which is extended to the dysphagia for the other facility of action in the treatment. Hereby the women of 71years which we have undertaken for the experiment is adjusted.

\section{Conclusion}

Even though it is rare, this complication deserves special attention, as long as the prognosis is directly related to the precocity of antagonizing and rigorous monitoring of the upper airways, in order to intervene in case of obstruction. The education of patients on oral anticoagulants is an essential step in order to minimize the management of time, for quick reference, and thus prompt management.

\section{References}

1. Delerme $S$ (2011) Accidents des traitements anticoagulants oraux. EMC Médecined'urgence 1-6. Link: https://goo.gl/iRgJ2X

2. Haute Autorité de Santé (2008) Good management practices for oral anticoagulant overdose, situations of hemorrhagic risk and hemorrhagic events in patients taking oral anticoagulants in the ambulatory and hospital setting--April 2008. J Mal Vasc 33: 202-213. Link: https://goo.gl/B9ewRe

3. Elalamy I (2007) Accidents des traitements anticoagulants oraux; EMC (Elsevier Masson SAS, Paris). MédecineD'urgence 25-190-B-10. Link: https://goo.gl/zGSNkW

4. González-García R, Schoendorff G, Muñoz-Guerra MF, Rodríguez-Campo FJ, NavalGías L, et al. (2006) Upper airway obstruction by sublingual hematoma: a complication of anticoagulation therapy with acenocoumarol. Am J Otolaryngol 27: 129-132. Link: https://goo.gl/9dR94v

5. Bahathiq AO (2018) Treatment of type 2 diabetes, GLP-1 Agonist and a DPP-4 Inhibitor. J Proteomics Enzymol 7:1. Link: https://goo.gl/bE8dK3

6. Gooder P, Henry R (1980) Impending asphyxia induced by anticoagulant therapy. J Laryngol Otol 94: 347-352. Link: https://goo.gl/DKpqTJ

7. Kounis NG, Zarras GM, Frangides C, Andreas A (1996) Lingual haematoma after treatment with alteplase (recombinant tissue plasminogen activator) for acute myocardial infarction. Heart 75: 427. Link: https://goo.gl/zBNMcy

8. Lee M, Berger HW, Granada MG (1980) Acute upper airway obstruction. Sodium warfarin-induced hemorrhage into the base of the tongue and epiglottis. Chest 77: 454-455. Link: https://goo.gl/aHP79p

9. Baglin TP, Keeling DM, Watson HG (2006) Guidelines on oral anticoagulation (warfarin): third edition-2005 update. Br J Haematol 132: 277-278. Link: https://goo.gl/yiygcF

10. Hing NR, Bowler MD, Byth PL (1985) Lingual haematoma leading to upper airway obstruction. $\mathrm{Br} \mathrm{J}$ Oral Maxillofac Surg 23: 322-325. Link: https://goo.gl/7ZuVpn

11. Saah D, Braverman I, Elidan J (1993) Traumatic macroglossia. Ann Otol Rhinol Laryngol 102: 729-730. Link: https://goo.gl/WNTkMe

12. Shaps HJ, Snyder GE, Sama AE (2001) Airway compromise secondary to lingual hematoma complicating administration of tissue plasminogen activator for ischemic stroke. Ann Emerg Med 38: 447-449. Link: https://goo.gl/UXyFdP 